Atmos. Chem. Phys., 13, 1879-1894, 2013

www.atmos-chem-phys.net/13/1879/2013/

doi:10.5194/acp-13-1879-2013

(c) Author(s) 2013. CC Attribution 3.0 License.

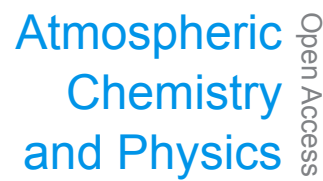

\title{
Receptor modelling of secondary and carbonaceous particulate matter at a southern UK site
}

\author{
A. Charron ${ }^{1}$, C. Degrendele ${ }^{1, *}$, B. Laongsri ${ }^{2}$, and R. M. Harrison ${ }^{2,3}$ \\ ${ }^{1}$ IFSTTAR, Institut Français des Sciences et Technologies des Transports, de l'Aménagement et des réseaux Laboratoire \\ Transport et Environnement, 25 Avenue François Mitterrand Case 24, 69675 Bron Cedex, France \\ ${ }^{2}$ National Centre for Atmospheric Science, Division of Environmental Health \& Risk Management, School of Geography, \\ Earth \& Environmental Sciences, University of Birmingham, Edgbaston Birmingham B15 2TT, UK \\ ${ }^{3}$ Department of Environmental Sciences/Center of Excellence in Environmental Studies, King Abdulaziz University, P.O. Box \\ 80203, Jeddah, 21589, Saudi Arabia \\ *now at: RECETOX, Faculty of Science, Masaryk University, Kamenice 3, 62500 Brno, Czech Republic
}

Correspondence to: R. M. Harrison (r.m.harrison@bham.ac.uk)

Received: 2 August 2012 - Published in Atmos. Chem. Phys. Discuss.: 17 October 2012

Revised: 22 January 2013 - Accepted: 4 February 2013 - Published: 19 February 2013

\begin{abstract}
Complementary approaches have been taken to better understand the sources and their spatial distribution for secondary inorganic (nitrate and sulphate) and secondary organic aerosol sampled at a rural site (Harwell) in the southern United Kingdom. A concentration field map method was applied to 1581 daily samples of chloride, nitrate and sulphate from 2006 to 2010, and 982 samples for organic carbon and elemental carbon from 2007 to 2010 . This revealed a rather similar pattern of sources for nitrate, sulphate and secondary organic carbon within western/central Europe, which in the case of nitrate, sulphate, organic carbon and secondary organic carbon, correlated significantly with EMEP emissions maps of $\mathrm{NO}_{\mathrm{x}}, \mathrm{SO}_{2}$, and $\mathrm{VOC}$ respectively. A slightly more southerly source emphasis for secondary organic carbon may reflect the contribution of biogenic sources. Trajectory clusters confirm this pattern of behaviour with a major contribution from mainland European sources. Similar behaviours of, on the one hand, sulphate and organic carbon and, on the other hand, EC and nitrate showed that the former are more subject to regional influence than the latter in agreement with the slower atmospheric formation of sulphate and secondary organic aerosol than for nitrate, and the local/mesoscale influences upon primary EC. However, careful analysis of back trajectories and Concentration Field Maps indicates a strong contribution of mainland European sites to EC concentrations at Harwell. In a separate study, measurements of sulphate, nitrate, elemental and organic carbon were made in
\end{abstract}

100 simultaneously collected samples at Harwell and at a suburban site in Birmingham (UK). This showed a significant correlation in concentrations between the two sites for all of the secondary constituents, further indicating secondary organic aerosol to be a regional pollutant behaving similarly to sulphate and nitrate.

\section{Introduction}

The European Union, in common with many other administrations, has established tough targets for air quality in order to limit adverse effects upon human health. There have long been limit values for $\mathrm{PM}_{10}$ of $40 \mu \mathrm{g} \mathrm{m}^{-3}$ annual mean with no more than 35 days per year exceeding a daily mean concentration of $50 \mu \mathrm{g} \mathrm{m}^{-3}$. However, a plan to strengthen this limit value in 2010 was deferred since some countries were unable to meet the pre-existing limit value. More recently, the EU (Official Journal, 2008) has set limit values for $\mathrm{PM}_{2.5}$ of $25 \mu \mathrm{g} \mathrm{m}{ }^{-3}$ to be met by 2015 and more importantly an exposure reduction target designed to reduce average population exposure to $\mathrm{PM}_{2.5}$ by the year 2020 . The latter operates on a sliding scale with larger percentage reductions of up to $20 \%$ required for those countries with higher $\mathrm{PM}_{2.5}$ concentrations.

Inevitably, the legislative pressures arising from air quality standards and guidelines turn attention to source attribution 
Table 1. Statistics of PM components and metrics measured at Harwell between 2006 and 2010 and included in the calculations. Concentrations in $\mu \mathrm{g} \mathrm{m}^{-3}$.

\begin{tabular}{|c|c|c|c|c|c|c|c|}
\hline & chloride & nitrate & sulphate & $\mathrm{OC}$ & $\mathrm{EC}$ & gravimetric $\mathrm{PM}_{2.5}$ & gravimetric $\mathrm{PM}_{10}$ \\
\hline mean & 1.27 & 2.61 & 2.15 & 2.33 & 0.45 & 14.9 & 18.2 \\
\hline SD & 1.31 & 3.32 & 1.86 & 1.41 & 0.76 & 8.7 & 10.9 \\
\hline median & 0.87 & 1.40 & 1.55 & 2.08 & 0.24 & 12.0 & 15.0 \\
\hline range & $0-10.24$ & $0.01-35.8$ & $0-15.9$ & $0.07-14.7$ & $<$ d.1-10.9 & $3-62$ & $2-79$ \\
\hline$N$ & \multicolumn{5}{|c|}{1,581} & 732 & 602 \\
\hline sampling time & & 2006-2010 & & \multicolumn{2}{|c|}{ 10/2007-2010 } & 09/2008-2010 & 2006-2010 \\
\hline
\end{tabular}

of particulate matter in its broadest sense, i.e. what source categories are responsible and what is their geographic distribution. In the case of the United Kingdom, Yin et al. (2010) have published source apportionment estimates for $\mathrm{PM}_{2.5}$ at an urban and a rural site in the West Midlands area. The data, based upon sampling only five days per month for twelve months at the two sites revealed a major contribution from secondary aerosol constituents. The same is true of $\mathrm{PM}_{10}$ (Yin and Harrison, 2008). In the case of $\mathrm{PM}_{2.5}$, Yin et al. (2010) reported for the urban background site that secondary ammonium sulphate comprised $36 \%$, secondary ammonium nitrate, $16 \%$ and secondary organic matter, $19 \%$. Large contributions of secondary aerosol constituents to $\mathrm{PM}_{10}$ and $\mathrm{PM}_{2.5}$ are observed in other European locations (e.g. Putaud et al., 2010; Carbone et al., 2010; Vercauteren et al., 2011; Im et al., 2012; Minguillon et al., 2012). Thus, overall, secondary components dominate the $\mathrm{PM}_{2.5}$ mass hence focussing attention on their properties with respect to developing abatement strategies. In the case of sulphate and nitrate, the chemical processes responsible for atmospheric formation are well known, although the relative importance of homogeneous and heterogeneous mechanisms is very difficult to discern, leading to major challenges for modelling their atmospheric production. In the case of secondary organic aerosol, the processes are far more complex involving a very wide range of precursors, and knowledge is relatively poor.

There are essentially two ways of gaining a better understanding of secondary aerosol sources and their geographic distribution. The most frequently used is the chemistrytransport model which yields valuable insights but depends critically on the parameterisation of the oxidation processes. It also requires a knowledge of the chemistry and physics of formation of secondary organic aerosol beyond that currently available. Consequently, although chemistry-transport models are an immensely important tool, there are considerable uncertainties associated with their predictions. The alternative is to use statistical receptor modelling methods which depend upon analyses of measured air quality data. A wide range of techniques now exist and these can provide important insights into the sources responsible for measured concentrations and the geographic distribution of those sources.

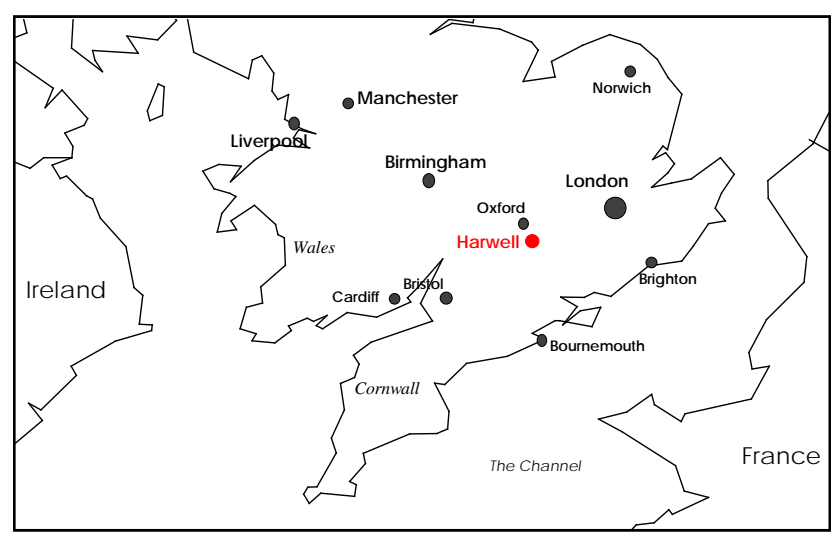

Fig. 1. Map of England with the locations of Harwell, Birmingham and London (stereographic projection true at $60^{\circ} \mathrm{N}$ ).

They also have disadvantages, including difficulties in unequivocal identification of sources by models such as CMB and PMF (Pant and Harrison, 2012) and a lack of quantification of source-receptor relationships by models such as the PSCF or CFMM model used in this study. In this paper, we deploy receptor modelling techniques in order to elucidate sources of secondary particulate matter components.

\section{Data and methods}

\subsection{Sampling sites}

\subsubsection{Harwell sampling supersite (regional background site)}

Particulate nitrate, sulphate, chloride, elemental and organic carbon and gravimetric $\mathrm{PM}_{10}$ and $\mathrm{PM}_{2.5}$ collected from January 2006 to December 2010 are included in this study (see Table 1 for a summary of the available data).

The Harwell observation site $\left(51^{\circ} 34^{\prime} 16^{\prime \prime} \mathrm{N} ; 1^{\circ} 19^{\prime} 31^{\prime \prime} \mathrm{W}\right)$ is representative for rural background concentrations of the southern parts of the United Kingdom (Fig. 1). The site is located $80 \mathrm{~km}$ almost due west of central London. It is in the grounds of the Harwell Science Centre in Oxfordshire and is on open land with agricultural fields. The nearest road is 
on the east of the Science Park, around 400 metres from the monitoring site, and used for access to the Research Centre only. The nearest trees are at a distance of 200-300 metres from the monitoring station. The sampling site is around $2 \mathrm{~km}$ from a busy four lane highway (A 34) located to the east $\left(10-170^{\circ}\right.$; the closest part, less than $2 \mathrm{~km}$ away is around 80 $120^{\circ}$ ) and about $7 \mathrm{~km}$ from the Didcot Power Station, a gas and coal-fired power station, located to the north east (30$40^{\circ}$ ), and industrial activities to the north north-east (Milton Park estate $6 \mathrm{~km}$ away, $10-30^{\circ}$ ). A careful analysis of data has shown a minimal influence of power station emissions on 24-h concentrations (Jones and Harrison, 2011). The closest village is the small Chilton village located to the east $2 \mathrm{~km}$ away, $88-108^{\circ}$.

In the dominant westerly wind direction, Harwell is influenced by maritime air masses from the North Atlantic. In the easterly directions, it is also influenced by aged air masses from Greater London or from continental Europe. Anthropogenic emissions are mostly located in these directions, and European continental air masses may pass over the London area receiving additional anthropogenic emissions before reaching the site. The Harwell site is a highly representative rural site from which to evaluate the regional background defined using the $\mathrm{PM}_{10}$ concentration measured at the rural sites (Charron et al., 2007).

\subsubsection{Elms Road Observatory Site (EROS)}

EROS $\left(52^{\circ} 27^{\prime} 13^{\prime \prime} \mathrm{N}, 1^{\circ} 55^{\prime} 41^{\prime \prime}\right)$ is an urban background site located in an open field within the Birmingham University campus. The site is about $3.5 \mathrm{~km}$ southwest of the centre of Birmingham, which has a population of over one million and is part of a conurbation of 2.5 million population. The nearest anthropogenic sources are a nearby railway, some moderately trafficked B roads (highways of intermediate traffic density) and other surrounding activities from the university and local residents. It is about $115 \mathrm{~km}$ to the NNW of Harwell.

\subsection{Sampling}

\subsubsection{Inorganic Anions (Sulphate, Nitrate and Chloride) collected at Harwell}

Daily sampling of the inorganic components of $\mathrm{PM}_{10}$ were made using a Thermo Partisol 2025 sequential air sampler. The Partisol samplers provide uninterrupted sampling of ambient air and automatic exchange of filters for up to 16 days. The instrument used an airflow of $16.7 \mathrm{~L}$ per minute through a $\mathrm{PM}_{10}$ inlet and the filter temperature was maintained to within $\pm 5^{\circ} \mathrm{C}$ of ambient temperature. Until October 2007, those samples were collected on glass fibre filters (Emfab, PTFE-bound glass fibre). From October 2007, ultra pure quartz filters have been used. Extracts from the filters were dissolved in an eluent of $3.5 \mathrm{mM}$ sodium carbonate and $1 \mathrm{mM}$ sodium hydrogen carbonate and analysed in the laboratory using ion chromatography according to the method of Yin and Harrison (2008). Ambient concentrations were derived from the mass measured on the filter and the airflow during the sampling period.

\subsubsection{Gravimetric $\mathbf{P M}_{10}$ and $\mathbf{P M}_{2.5}$ collected at Harwell}

Two Partisol instruments measured simultaneously the $\mathrm{PM}_{10}$ and $\mathrm{PM}_{2.5}$ particles on a daily basis.

Quartz fibre filters (Whatman QMA $47 \mathrm{~mm}$ diameter filters, $0.6 \mathrm{~mm}$ pore size) have been used for the collection of particulate matter. Pre-conditioning and post-conditioning of filters were undertaken in accordance with the requirements of prEN 12341. Blank and dust-loaded filters are handled according to the same protocols.

\subsubsection{Elemental and Organic Carbon (EC and OC) collected at Harwell}

Two datasets, both involving sampling at the Harwell site were analysed. The main dataset (2006-2010) was collected daily at the Harwell site by the National Physical Laboratory using a Partisol sampler with a $\mathrm{PM}_{10}$ inlet and a flow rate of $16.7 \mathrm{~L} \mathrm{~min}^{-1}$ on quartz fibre filters. Collected samples were analysed using the QUARTZ protocol using both reflectance and transmittance corrections for pyrolytic carbon on a Sunset Laboratory thermal-optical carbon analyser. For consistency with the second dataset (from Harwell and EROS - see below), transmittance correction was preferred, and for data points for which only reflectance corrected data were available, the data were converted to transmittance using relationships derived from linear regression (i.e. for OC, reflectance $=0.92$ transmittance, $R^{2}=0.95$, and for $\mathrm{EC}$, reflectance $=1.42$ transmittance, $R^{2}=0.77$ ).

\subsubsection{Data collected at Harwell and EROS site}

The second dataset was collected simultaneously at the Harwell and EROS sites from July 2010 to November 2010 using a Partisol 2025D dichotomous sampler so as to collect separate coarse $\left(\mathrm{PM}_{2.5-10}\right)$ and fine $\left(\mathrm{PM}_{2.5}\right)$ particle fractions on QMA quartz fibre filters, after correction of the coarse particle load for a small fine particle component. The samples were analysed on a Sunset Laboratory Thermal-Optical instrument using the EUSAAR 2 protocol (Cavalli et al., 2010). The two Harwell datasets were intercompared, showing an acceptable level of agreement given the different protocols and lack of simultaneous sampling (sample start times were out of phase by $12 \mathrm{~h}$ ). EC, $\mathrm{y}=0.97 \mathrm{x}+0.09 \mu \mathrm{g} \mathrm{m}^{-3}$; $r^{2}=0.31$ and for TC, $\mathrm{y}=0.90 \mathrm{x}+1.07 \mu \mathrm{g} \mathrm{m}^{-3} ; r^{2}=0.28$, where $\mathrm{y}=$ second dataset and $\mathrm{x}=$ first dataset. A small intercomparison of the QUARTZ and EUSAAR 2 protocols on the same samples has shown almost identical results (Paul Quincey, personal communication). In neither case were 
corrections attempted for either positive or negative sampling artefacts.

\subsubsection{Data available}

Data used in this study are presented in Table 1. Table 2 presents the data used for the examination of seasonal influences. For this examination, the warm season is defined by the data collected between the months of May to September and the cold season is defined by the data comprised between the months of October to April. The smaller dataset $(\mathrm{n}=$ 100) collected simultaneously at Harwell and EROS appears in Table 3.

\subsubsection{Estimation of secondary OC (SOC) and primary $\mathbf{P M}_{10}$}

A method similar to that used in Harrison et al. (2003), Yin and Harrison (2008) and Yin et al. (2010) has been used. It assumes that EC is inert and is from primary emissions only and that the ratio OC/EC of primary emissions is known. Ambient OC/EC values higher than the ratio of primary emissions are an indication that a part of OC is SOC. This method was modified to use a primary OC:EC ratio of 0.35 as concluded by Pio et al. (2011). This ratio is representative of primary emissions from road traffic. Other primary emissions, most notably wood burning would be incorrectly classified as secondary, but are not thought to be a significant contributor at our sites. Measurements of levoglucosan at EROS (Harrison et al., 2012) indicate low wood smoke concentrations and the ratio of OC/EC in the urban increment above rural concentrations in Birmingham is close of 0.35 (Yin and Harrison, 2008) indicative of traffic as the dominant local primary source. If wood burning were to be a significant source, the calculated SOC concentrations would be higher in winter than summer, which is not the case (see Table 2). The Harwell site is within a large science park and unlikely to be influenced by local wood burning sources. Hence:

- The organic content of $\mathrm{PM}_{10}$ is split into a primary and a secondary fraction using: Secondary $\mathrm{OC}=$ measured OC -0.35 * measured EC

- For the calculation of the primary $\mathrm{PM}_{10}$ fraction, the secondary organic carbon mass is converted to the organic compounds mass using a factor of 1.8 (from secondary OC to secondary OM - based on the work of Utembe et al., 2009); sulphate and nitrate are converted into ammonium salts (without bound water). Then, the primary $\mathrm{PM}_{10}$ is calculated as followed: Primary $\mathrm{PM}_{10}=$ measured $\mathrm{PM}_{10}-$ secondary $\mathrm{OM}-\left(\mathrm{NH}_{4}\right)_{2} \mathrm{SO}_{4}$ $-\mathrm{NH}_{4} \mathrm{NO}_{3}$

This fails to account for sea salt sulphate which, based upon a $\mathrm{Cl}^{-} / \mathrm{SO}_{4}^{2-}$ ratio of 0.14 amounts on average to $<0.2 \mu \mathrm{g} \mathrm{m}^{-3}$, or about $8 \%$ of sulphate in the main Harwell dataset.

\subsection{Meteorological data}

Wind speed and wind direction data measured directly at the Harwell sampling site are used in this study. These data were available from January 2006 to December 2008 on the UK National Air Quality Archive. The temperature data used in this study were measured at the Benson station which is the closest $(16 \mathrm{~km})$ from the Harwell monitoring site. These data have been supplied by the British Atmospheric Data Centre (BADC).

Air mass back trajectories supplied by the BADC were used to estimate the pathways followed by air masses arriving at Harwell. BADC 3-dimensional backwards trajectories were calculated from interpolations of 6h-ECMWF input wind fields.

\subsection{Concentration field map method}

In this study the concentration field map method of Charron et al. (2008) has been applied to 2006-2010 data associated with corresponding 5-day backward trajectories (the largest datasets available are used, see Table 1). Concentration field map methods (CFMM) combine air pollution data and backwards trajectories to establish concentration field maps of likely contributing sources. A number of CFMM have been used to identify regional sources of pollutant measured at a receptor site e.g. the Ashbaugh method (Ashbaugh, 1983), often called Potential Source Contribution Function or PSCF, the Seibert method (Seibert et al., 1994); the Stohl method (Stohl, 1996) and the Simplified Quantitative Transport Bias Analysis or SQTBA (Zhou et al., 2004). They are purely statistical models and as a consequence, no physical or chemical processes are included. Geographical areas identified by these models must be seen as potential source areas contributing to concentration values measured at receptor sites. Concentration field map methods have been compared and all give satisfactory results (Charron et al., 1998; Lupu and Maenhaut, 2002; Zhou et al., 2004).

The method used in this paper is a modification of the Seibert method (as used by Charron et al., 2008). The Seibert Method is equivalent to the geometric mean of concentrations attributed to each grid cell. The geometric mean is biased low as an estimator of the true mean of population following log-normal distributions and is generally not the preferred estimator for environmental data (Parkhurst, 1998). The method used computes median particle concentrations rather than geometric means (Charron et al., 2008).

The pathways of air masses are described by 0.5 -h trajectory segment endpoints of coordinates in terms of latitude and longitude. Each daily concentration is associated with the two backward trajectories finishing at $6 \mathrm{~h}$ and $18 \mathrm{~h}$ GMT at Harwell each day (6h and $18 \mathrm{~h}$ are better than $0 \mathrm{~h}$ and $12 \mathrm{~h}$ if we consider the sampling times used to collect air pollution data). Since 120-h backward trajectories are used and each one corresponds to 240 endpoint locations, 
Table 2. Medians, 75th and 25th percentiles and arithmetic mean concentrations of chloride, nitrate, sulphate, organic carbon (OC), elemental carbon (EC) and secondary organic carbon (SOC) for the cold season (October to April) and warm season (May to September). Concentrations in $\mu \mathrm{g} \mathrm{m}^{-3}$. The Mann Whitney $\mathrm{U}$ test tested the $\mathrm{H} 0$ hypothesis that the distributions are the same in both seasons. ${ }^{* *}$ means that the significance level is 0.01 and ${ }^{*}$ means that the significance level is 0.05 .

\begin{tabular}{|c|c|c|c|c|c|c|c|}
\hline Season & Statistics & Chloride & Nitrate & Sulphate & $\mathrm{OC}$ & $\mathrm{EC}$ & SOC \\
\hline & $N$ & 887 & 887 & 887 & 578 & 578 & 578 \\
\hline Cold & median & 1.20 & 1.86 & 1.49 & 1.98 & 0.34 & 1.83 \\
\hline Cold & p0.75 & 2.19 & 4.57 & 2.73 & 2.78 & 0.72 & 2.54 \\
\hline Cold & $\mathrm{p} 0.25$ & 0.64 & 0.85 & 0.91 & 1.31 & 0.06 & 1.25 \\
\hline \multirow[t]{2}{*}{ Cold } & mean & 1.64 & 3.45 & 2.21 & 2.30 & 0.57 & 2.10 \\
\hline & $N$ & 694 & 694 & 694 & 404 & 404 & 404 \\
\hline Warm & median & 0.39 & 1.09 & 1.63 & 2.20 & 0.10 & 2.13 \\
\hline Warm & p0.75 & 1.09 & 1.87 & 2.52 & 3.04 & 0.45 & 2.98 \\
\hline Warm & p0.25 & 0.15 & 0.66 & 1.12 & 1.49 & 0.00 & 1.43 \\
\hline Warm & mean & 0.79 & 1.54 & 2.07 & 2.38 & 0.28 & 2.28 \\
\hline \multicolumn{2}{|c|}{ Mann-Whitney U test } & Reject H0 (**) & Reject H0 (**) & Retain H0 & Reject H0 (*) & Reject H0 (**) & Reject H0 $\left({ }^{* *}\right)$ \\
\hline
\end{tabular}

Table 3. Statistical data for $\mathrm{EC}, \mathrm{OC}, \mathrm{OC}_{\text {prim }}$ and $\mathrm{OC}_{\mathrm{sec}}\left(\mu \mathrm{g} \mathrm{m}^{-3}\right)$ at EROS and Harwell sites collected simultaneously, $(\mathrm{OC} / \mathrm{EC})_{\mathrm{min}}=0.35$; $n=100$.

\begin{tabular}{|c|c|c|c|c|c|c|}
\hline & \multicolumn{2}{|c|}{$\mathrm{PM}_{2.5}$} & \multicolumn{2}{|c|}{$\mathrm{PM}_{2.5-10}$} & \multicolumn{2}{|c|}{$\mathrm{PM}_{10}$} \\
\hline & Mean & Range & Mean & Range & Mean & Range \\
\hline \multicolumn{7}{|l|}{ EROS } \\
\hline $\mathrm{EC}$ & $1.0 \pm 1.1$ & $0.2-8.2$ & $0.04 \pm 0.1$ & $<\mathrm{dl}-0.5$ & $1.0 \pm 1.1$ & $0.2-8.3$ \\
\hline OC & $2.3 \pm 1.6$ & $0.9-12.1$ & $1.2 \pm 0.6$ & $0.5-5.3$ & $3.5 \pm 1.8$ & $1.6-13.7$ \\
\hline $\mathrm{OC}_{\text {prim }}$ & $0.4 \pm 0.4$ & $0.1-2.9$ & n.a & n.a & $0.4 \pm 0.4$ & $0.1-2.9$ \\
\hline $\mathrm{OC}_{s e c}$ & $2.0 \pm 1.3$ & $0.7-9.2$ & n.a & n.a & $3.1 \pm 1.5$ & $1.4-10.8$ \\
\hline Nitrate & $1.61 \pm 2.11$ & $<\mathrm{dl}-10.88$ & $0.63 \pm 0.64$ & $<\mathrm{dl}-3.29$ & $2.25 \pm 2.49$ & $<\mathrm{dl}-12.49$ \\
\hline Sulphate & $1.60 \pm 1.35$ & $0.32-6.48$ & $0.25 \pm 0.17$ & $<\mathrm{dl}-0.89$ & $1.85 \pm 1.47$ & $0.55-7.37$ \\
\hline \multicolumn{7}{|c|}{ HARWELL } \\
\hline $\mathrm{EC}$ & $0.4 \pm 0.4$ & $<\mathrm{dl}-1.9$ & $0.03 \pm 0.1$ & $<\mathrm{dl}-0.5$ & $0.4 \pm 0.4$ & $<\mathrm{dl}-2.2$ \\
\hline $\mathrm{OC}$ & $1.8 \pm 0.9$ & $0.5-4.8$ & $1.0 \pm 0.5$ & $0.4-3.3$ & $2.8 \pm 1.1$ & $1.0-7.0$ \\
\hline $\mathrm{OC}_{\text {prim }}$ & $0.1 \pm 0.1$ & $<\mathrm{dl}-0.7$ & n.a & n.a & $0.1 \pm 0.2$ & $<\mathrm{dl}-0.8$ \\
\hline $\mathrm{OC}_{\mathrm{sec}}$ & $1.6 \pm 0.8$ & $0.5-4.5$ & n.a & n.a & $2.7 \pm 1.0$ & $0.9-6.6$ \\
\hline Nitrate & $1.44 \pm 2.02$ & $0.03-11.65$ & $0.71 \pm 0.68$ & $<\mathrm{dl}-0.89$ & $2.16 \pm 2.50$ & $0.16-14.75$ \\
\hline Sulphate & $1.47 \pm 1.24$ & $0.05-6.76$ & $0.35 \pm 0.40$ & $<\mathrm{dl}-2.36$ & $1.82 \pm 1.40$ & $0.36-7.53$ \\
\hline
\end{tabular}

n.a. $=$ not available.

480 endpoint locations are associated with each daily particle concentration. The whole geographic region covered by the trajectories is divided into $150 \times 150 \mathrm{~km}$ grid cells corresponding to the EMEP grid of Europe that is a stereographic projection true at $60^{\circ} \mathrm{N}$. When a trajectory passes across a cell, it is assumed that pollutants emitted within this cell are incorporated into the air mass represented by the trajectory and are transported to the receptor site. No physical and chemical processes are included in this model; transformation and sink processes between emission sources and the receptor site are intrinsically assumed for interpretation when known, or neglected. It is arbitrarily chosen that grid cells with less than 20 trajectory endpoints have a too low statisti- cal significance to be retained and calculations are done only with grid cells counting more than or equal to 20 trajectory endpoints.

A concentration value $\mathrm{C}_{\mathrm{nm}}$ attributed to a grid cell (n, m) represents the average concentrations measured at the receptor site when air masses come from the geographical area defined by the grid cell (n, m). A large dataset is necessary to ensure the statistical significance of the results.

A scale of 5 colours from light yellow to brown is used for the representation of different groups of median concentrations in $\mu \mathrm{g} \mathrm{m}^{-3}$. Grid cells in white correspond to grid cells with less than 20 trajectory endpoints. 


\subsection{EMEP emission data}

In order to realize a qualitative and quantitative comparison between the results from the Concentration Field Map method and the maps of the total European emissions, $\mathrm{NO}_{2}$, $\mathrm{SO}_{2}, \mathrm{NMVOC}, \mathrm{PM}_{2.5}$ and $\mathrm{PM}_{10}$ emission data for the year 2008 from 25 countries of Europe have been supplied by the Centre on Emissions Inventories and Projection (CEIP). EMEP emissions are based on a combination of official reported data from European countries supplemented with corrections and expert estimates for missing data and/or for data of low quality.

As the emission data from CEIP were available on $50 \times 50 \mathrm{~km}$ grid cells, the emissions corresponding to $150 \times 150 \mathrm{~km}$ grid cells are computed in order to compare them with data obtained with the Concentration Field Map Method (that uses the former emission map with $150 \times 150$ grid cells).

\subsection{Trajectory clusters}

The K-mean clustering method was applied to backward trajectories from 2006 to 2010 ( $5 \mathrm{yr}$ ). Cluster analysis uses the degree of similarity and difference between individual observations to define the groups and to assign group membership (Wilks, 1995). The aim is to split existing multidimensional data into subgroups (clusters) which are as different as possible from each other, but as homogeneous as possible within themselves. The K-mean procedure ensures that a large number of samples can be handled (contrary to cluster hierarchical methods) and has often been successfully applied to atmospheric data (Wilks, 1995). The measure of distance between individual samples used here is the Euclidean distance computed from the geographical eastings and northings of trajectory points. The final cluster centres are computed as the mean for each variable within each final cluster. Since each backward trajectory is associated with a set of particle concentrations measured at Harwell, clusters could be associated with average particle concentrations.

\section{Results and discussion}

\subsection{Concentrations measured at Harwell and temporal behaviour}

Table 1 presents the concentrations available for this study and median and mean concentrations from 2006 to 2010. Not all measurements started in 2006 and the largest datasets available are included in the statistical calculations. Arithmetic mean values for all pollutants were higher than median values indicating the influence of episodic high concentrations (Table 1). The difference between mean and median values is the strongest for nitrate and EC and the least for OC. Nitrate and EC are the two particulate pollutants with concentrations that show the greatest variability as also shown by the standard deviations which are larger than mean concentrations (contrary to sulphate and OC). Similar to other observations in Europe (e.g. Lonati et al., 2008), OC largely dominates the carbonaceous species accounting on average $84 \%$ of the total carbon $(\mathrm{TC}=\mathrm{OC}+\mathrm{EC})$.

Sulphate and nitrate, which are mainly due to anthropogenic sources, follow a quite similar pattern for the period studied (Fig. S1 in the Supplement). The monthly median concentrations of sulphate and nitrate are significantly correlated $\left(r_{\text {Spearman }}=0.62\right.$, significant at the 0.01 level $)$ indicating quite similar temporal variations. However, monthly median nitrate concentrations were higher during the cold season, while no seasonal variation is seen for sulphate. Interestingly, monthly median concentrations of sulphate also show significant correlations with monthly median concentrations of OC $\left(r_{\text {Spearman }}=0.39\right.$, significant at the 0.05 level $)$ and SOC $\left(r_{\text {Spearman }}=0.41\right.$, significant at the 0.05 level $)$; while it does not show any significant relationship with monthly median concentrations of EC $\left(r_{\text {Spearman }}=0.20\right)$. The absence of significant correlation between OC and EC suggests no single dominant source for the two carbon species. On the contrary, the correlation between sulphate and OC or SOC may be explained by the mainly secondary origin of these two components that originate from the oxidation of other atmospheric compounds that are slowly transformed in the atmosphere between emission sources and Harwell. Their similar trend (both decreased from 2006 to 2010) may also explain the good agreement. Perhaps more surprisingly, monthly median nitrate concentration does not show any correlation with OC $\left(r_{\text {Spearman }}=0.01\right)$ and SOC $\left(r_{\text {Spearman }}=-0.06\right)$ but a strong correlation with EC $\left(r_{\text {Spearman }}=0.60\right.$, significant at the 0.01 level). Different hypotheses may explain this significant correlation. First, nitrate and EC may be from common combustion sources/source areas at more local or short-range distances than sources responsible for sulphate and SOC (see Wagstrom and Pandis, 2011) in agreement with observations in other locations (Zhao et al., 2007; Carbone et al., 2010). The seasonal variations of EC and nitrate with higher concentrations during the cold season may also contribute to the significant correlation between these two components. Also, even though nitrate and EC show a decrease from 2006 to 2010, this decrease is much less important than that of sulphate and OC. Not surprisingly, the chloride does not show any correlation with the other particulate compounds in agreement with its mainly sea-salt origin at Harwell. Similar conclusions could be drawn using parametric Pearson correlation coefficients (note that the non-parametric Spearman correlation does not assume a linear relationship between compounds unlike the Pearson method).

Monthly median concentrations of nitrate show an inverse relationship to temperature (see Figure S2 and $r_{\text {Spearman }}=-$ 0.46 , significant at the 0.01 level), which is one of the key influencing factors since low temperatures favour the partitioning of ammonia and nitric acid into particulate ammonium nitrate (Stelson and Seinfeld, 1982). On the 
contrary, sulphate, OC and SOC do not show any relationship with air temperature $\left(r_{\text {Spearman }}=0.04 / 0.14 / 0.27\right.$ respectively). EC also shows an inverse relationship to temperature $\left(r_{\text {Spearman }}=-0.60\right.$, significant at the 0.01 level $)$ that can be explained by more active sources during the cold season (influence of residential fuel combustion) and poorer mixing in the winter months. The strong inverse relationship between chloride and air temperature is likely to be due primarily to the more frequent fast-moving polar air masses responsible for higher concentrations of chloride during the cold season (see below). If ammonium chloride were present, this would be subject to evaporative loss causing a decline in concentrations with temperature.

During the cold season, the mean concentration of nitrate was $3.45 \mu \mathrm{g} \mathrm{m}^{-3}$, whereas for the warm season it was $1.54 \mu \mathrm{g} \mathrm{m}^{-3}$ (i.e. $55 \%$ lower) (Table 2). Concentrations of nitrate measured during the cold season are significantly larger than those measured during the warm season (significances are tested using the Mann-Whitney U test, see Table 2). Peaks of nitrate are often observed in early spring. This observation is agreement with those in Italy (Lonati et al., 2008) and in the US (Park et al. 2005) but in disagreement with Artiñano et al. (2004) in Spain who found an increase of the nitrate concentration during the warm season due to more active conditions of photochemical formation of this pollutant. Again, the arithmetic mean for the nitrate is obviously influenced by very high values and the seasonal variations are much weaker than suggested by the arithmetic means. Indeed, the difference between warm and cold seasons for the nitrate is lower (about $41 \%$ ) considering the median than considering the mean concentrations. It is clear that the effects of stronger photochemical activity at Harwell in the warm season are hidden due to the transfer of particulate nitrate to gaseous ammonia and nitric acid. Also, the increase of mixing depth in summer over winter influences seasonal variations by mixing pollutants through a deeper boundary layer in the warmer months. Revuelta et al. (2012) comment upon the processes in more detail.

Considering sulphate, the mean concentration of this component is quite similar in the warm season to the cold season. Indeed, for the warm season, the mean concentration for sulphate is $2.07 \mathrm{\mu g} \mathrm{m}^{-3}$ and for the cold season, it is $2.21 \mu \mathrm{g} \mathrm{m}^{-3}$, whereas for the whole data set studied, it was $2.15 \mu \mathrm{g} \mathrm{m}^{-3}$. Contrary to the mean concentrations (again, that may be strongly influenced by a few high concentrations), the median concentration of sulphate during the warm season is slightly higher than that in the cold season. Depending on the location, sulphate may exhibit a seasonal variation with higher concentrations during the summer period (e.g. Glavas et al., 2008) or no seasonal variation similarly to Harwell (e.g. Lonati et al., 2008). Lonati et al. (2008) hypothesized that higher emissions of precursor $\mathrm{SO}_{2}$ in winter are offset by the enhanced secondary formation by oxidation during the summer months. The greater mixed layer depth in the summer is also likely to be an important factor.
In the cases of OC and SOC, even though differences between mean and median concentrations for both seasons are weak, OC and SOC concentrations are significantly higher during the warm season than during the cold season (significance level $=0.01$, Mann-Whitney test). This is in agreement with the stronger photochemical conditions of the warm season that favour the formation of SOC (that dominates the OC mass according to the model used). The weak difference between averages for warm and cold seasons may be due to the semi-volatile nature of SOC that partitions partly into the gaseous phase during the warmer months, or by higher emissions of anthropogenic organic precursors during the colder months.

In agreement with the strong inverse relationship between chloride and temperature, concentrations of chloride are significantly higher during the cold season.

\subsection{Identification of possible local and mesoscale influence}

An examination of the influence of the wind direction has been conducted (Fig. 2). Relationships to wind direction are useful to detect any local influence; while, associations with back trajectories provide information on long-range transport, and a better understanding of possible regional influences. A local influence is generally associated with a narrow wind direction sector responsible for significantly higher concentrations, while influences from more distant sources lead to a less well defined directional elevation as a consequence of there being a spread of pathways for approaching air masses. Figure 2 shows that the concentrations of all particulate components other than chloride at Harwell are higher when the wind blows from easterly directions. Sulphate and nitrate show a general increase in concentrations associated with easterly wind directions. The importance of the NE and E sectors for nitrate and sulphate (Fig. 2) is probably reflective of the high source strengths for precursor gases in some central and north-eastern European countries. On the contrary, the EC shows a more marked E-SE direction that exactly corresponds to the closest parts of the A34 highway. It is concluded that the diesel traffic of the A34 highway around $2 \mathrm{~km}$ away has probably influenced EC concentrations measured at Harwell. The behaviour of OC is somewhere between sulphate/nitrate and EC suggesting possible mixed local and regional influences with a much smaller influence of local vehicle emissions than for EC.

An attempt to examine the influence of Greater London emissions on particle concentrations measured at Harwell was conducted without success. Despite the large database available, the number of data points proved insufficient to examine statistically the influence of pollutant transport from London without interference from other influencing variables (winds from the A34 highway also located to the East, wind speed and transport from different source emission areas on a regional scale). 


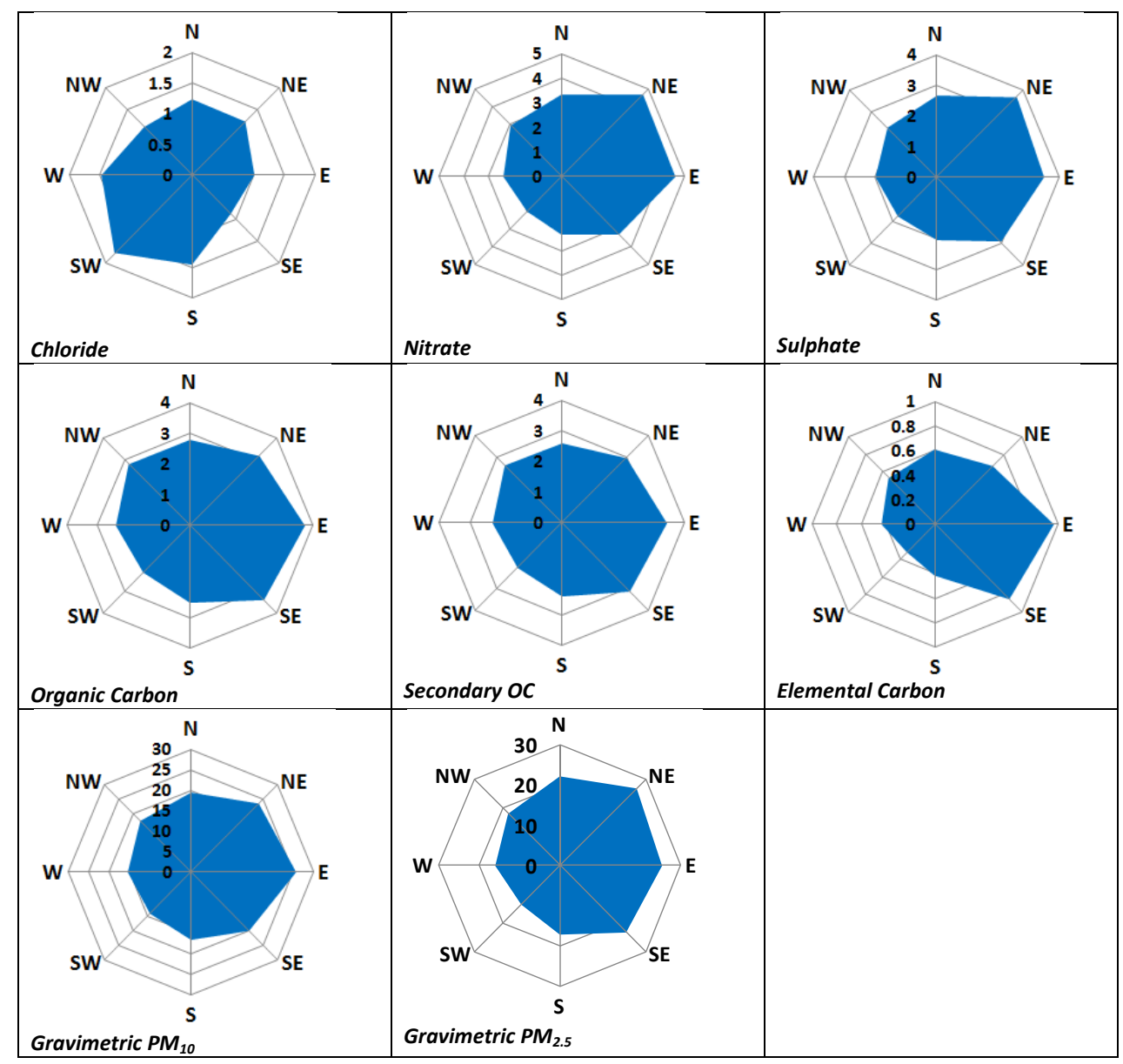

Fig. 2. Median concentrations per wind sector in $\mu \mathrm{g} \mathrm{m} \mathrm{m}^{-3}$.

\subsection{Identification of potential regional source areas}

The identification of source regions has been performed through the Concentration Field Map Method (CFMM) and trajectory clustering. Figures 3 and 4 show the Concentration Field maps for chloride, nitrate, sulphate, organic carbon, secondary organic carbon, elemental carbon, gravimetric $\mathrm{PM}_{2.5}$ and gravimetric $\mathrm{PM}_{10}$. The Concentration Field Map for chloride is seen in Fig. 3a. Primarily, as expected, it attributes chloride mainly to marine areas as its main source is seawater, with an emphasis on the longer (i.e. faster with higher wind speed) trajectories. The main potential sources were the Atlantic Ocean, the North Sea, and the Baltic Sea. There is however a notable potential source over northern Europe, which may be due to emissions of $\mathrm{HCl}$ from coal combustion, or related to the lower temperature of these trajectories limiting volatile loss of $\mathrm{NH}_{4} \mathrm{Cl}$. An apparent source over northern Spain may arise from primary sources, or more probably appears because air masses from that source region cross the ocean collecting marine chloride before reaching our sampling site.
Figure $3 \mathrm{c}$ shows a strong relationship between sulphate and areas of high sulphur dioxide emission in central Europe. It is likely there is also a major contribution from Eastern Europe, but this is not shown by the concentration field map because of the sparseness of trajectories crossing the more distant grid squares and therefore the lack of statistical significance of the results. However, there was a highly significant correlation of the concentration field map with EMEP emissions of $\mathrm{SO}_{\mathrm{x}}$ with a Spearman Rank correlation $r=0.65$; $p<0.01$. The highest concentrations of particulate sulphate, which is an indicator of aged air masses and long range transport, were associated with a continental origin, and more precisely, from the region from northeast France and Central Europe as potential source areas. The results for particulate sulphate and chloride data give confidence in the CFMM results since chloride is an indicator of maritime origin and sulphate is an indicator of aged air masses. Cells showing slightly elevated levels to the extreme west of the sulphate map correlate with elevated chloride and may reflect sea salt sulphate.

In the case of the nitrate, the main potential sources are also located in continental Europe, (Fig. 3b). Concentrations 
(a)

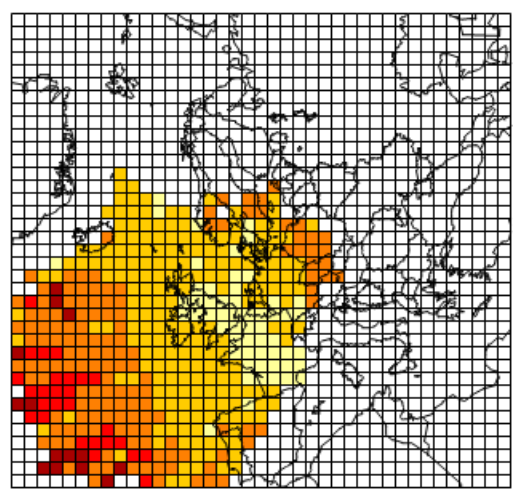

$\square$ below $0.7 \mu \mathrm{g} / \mathrm{m}^{3} \square 0.7-1.5 \mu \mathrm{g} / \mathrm{m}^{3} \square_{1.5-2.5 \mu \mathrm{g} / \mathrm{m}^{3}}$ $\square 2.5-3 \mu \mathrm{g} / \mathrm{m}^{3} \square$ above $3 \mu \mathrm{g} / \mathrm{m}^{3}$

(c)

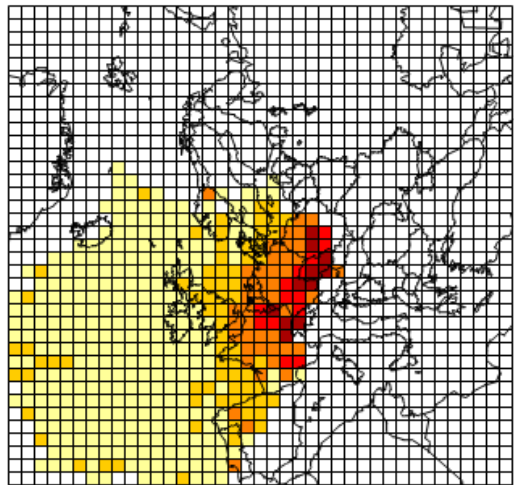

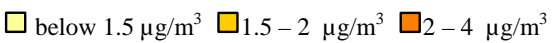

$\square_{4-5 \mu \mathrm{g} / \mathrm{m}^{3}} \square$ above $5 \mu \mathrm{g} / \mathrm{m}^{3}$ (b)

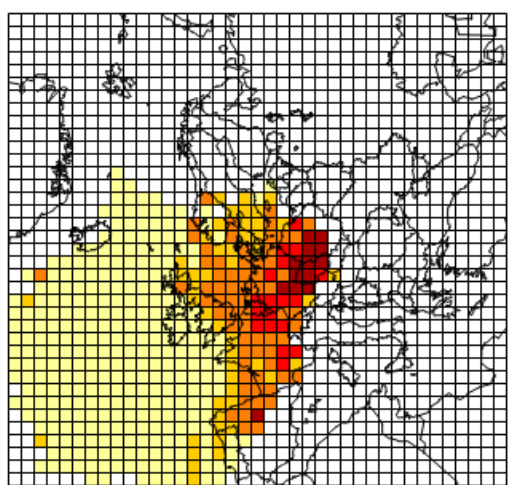

$\square$ below $1.5 \mu \mathrm{g} / \mathrm{m}^{3} \square 1.5-2 \mu \mathrm{g} / \mathrm{m}^{3} \square_{2-4} \mu \mathrm{g} / \mathrm{m}^{3}$

$\square_{4-5 \mu \mathrm{g} / \mathrm{m}^{3}} \square_{\text {above }} 5 \mu \mathrm{g} / \mathrm{m}^{3}$

(d)

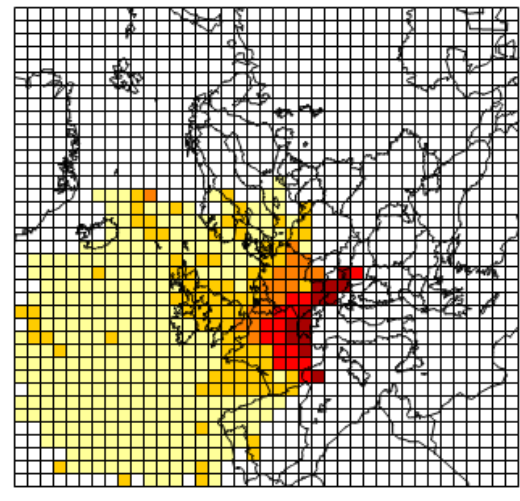

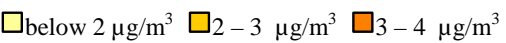

$\square 4-5 \mu \mathrm{g} / \mathrm{m}^{3} \square_{\text {above }} 5 \mu \mathrm{g} / \mathrm{m}^{3}$

Fig. 3. Concentration field map of (a) particulate chloride; (b) particulate nitrate (c) sulphate (d) particulate OC.

larger than $4 \mu \mathrm{g} \mathrm{m}^{-3}$ are associated with the European areas with strong $\mathrm{NO}_{\mathrm{x}}$ emissions. This is confirmed by a highly significant correlation between the map and the EMEP emissions database (Spearman rank correlation $r=0.67$; $p<0.001)$. Note that this correlation coefficient shows the agreement between the cells of the entire European domain and as a consequence is a representation of the importance of the regional contribution. In the case of nitrate this is probably affected by mesoscale sources (see below), but cells around Harwell do not influence the degree of correlation more than the other cells.

Figure $3 \mathrm{~d}$ shows the concentration field map for particulate organic carbon and Figure 4a for secondary organic carbon. The two graphs bear a strong similarity since the estimated secondary organic carbon dominates the overall concentration. These maps also bear some similarity to that of sulphate but with a more southerly emphasis than for sulphate, possibly reflecting the importance of emissions of biogenic VOC as precursors of secondary organic aerosol. In particular, the high source strength indicated over France is reflective of the pattern of biogenic VOC emissions (Simpson et al., 1995) and the large biogenic contribution to sec- ondary organic aerosol sampled over the UK (Heal et al., 2011). Correlations with the EMEP non-methane VOC emissions were significant for both OC (Spearman rank correlation $\mathrm{r}=0.551 ; p<0.01)$ and for SOC (Spearman $r=0.515$; $p<0.01$ ).

The maps for elemental carbon (Fig. 4b), gravimetric $\mathrm{PM}_{10}$ (Fig. 4c) and gravimetric $\mathrm{PM}_{2.5}$ (Fig. 4d) show broad similarities to one another probably reflecting the importance of population density as a major determinant of emissions of primary particles and the precursors of secondary aerosol. The map of EC indicates that a part of EC measured at Harwell is transported from the continent. Recent work has estimated an atmospheric lifetime of 4-12 days for black carbon (Cape et al., 2012), which demonstrates a strong capability for atmospheric transport. The map also indicates that the EC also has a local/mesoscale origin (since high concentrations are attributed to England). This is in agreement with the observations of Wagstroma and Pandis (2011) who associated EC measured at a rural site in part with local emissions, short-range emissions transport (within $100 \mathrm{~km}$ ) and mid and long-range transport in contrast to the more regional contributions to secondary organic aerosol and 
(a)

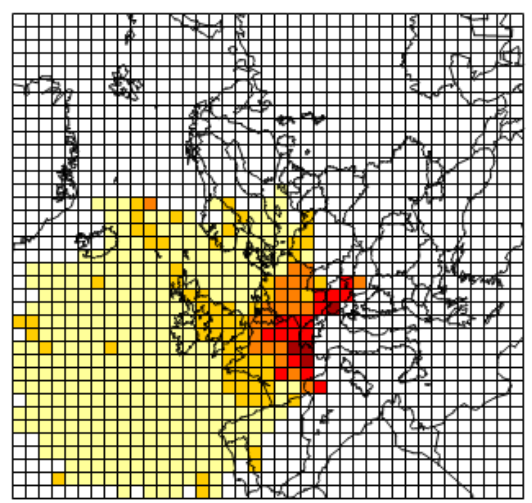

$\square$ below $2 \mu \mathrm{g} / \mathrm{m}^{3} \square 2-3 \mu \mathrm{g} / \mathrm{m}^{3} \square 3-4 \mu \mathrm{g} / \mathrm{m}^{3}$

$\square 4-5 \mu \mathrm{g} / \mathrm{m}^{3} \square$ above $5 \mu \mathrm{g} / \mathrm{m}^{3}$

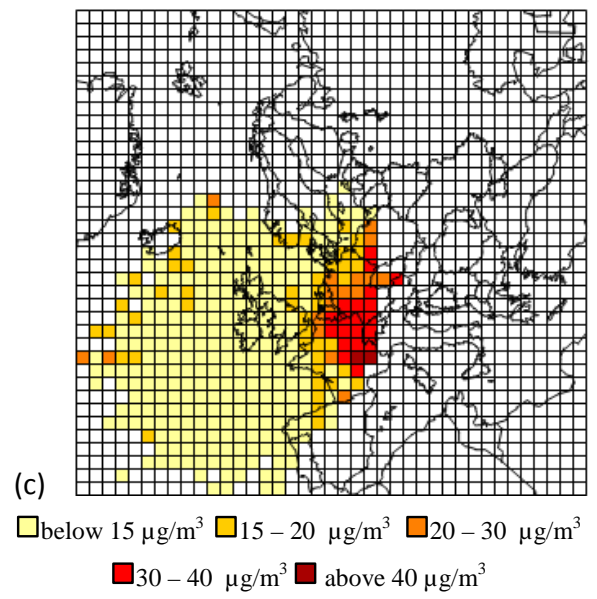

(b)

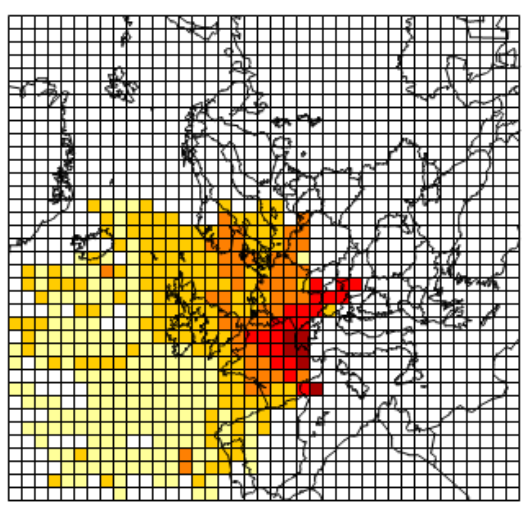

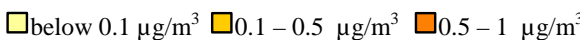

$\square 1-2 \mu \mathrm{g} / \mathrm{m}^{3} \square$ above $2 \mu \mathrm{g} / \mathrm{m}^{3}$

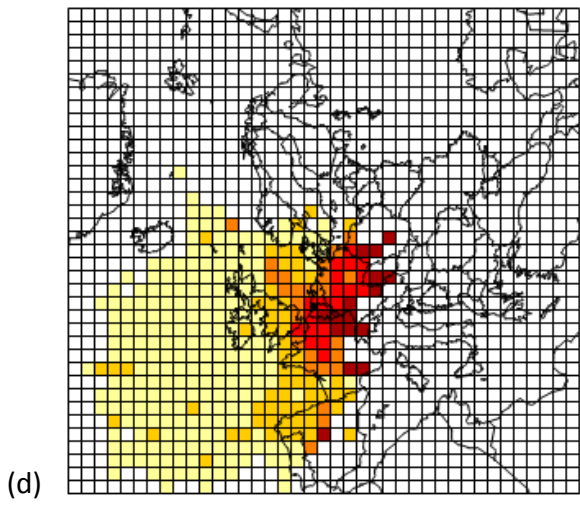

$\square$ below $15 \mu \mathrm{g} / \mathrm{m}^{3} \square_{15}-20 \mu \mathrm{g} / \mathrm{m}^{3} \square_{20}-30 \mu \mathrm{g} / \mathrm{m}^{3}$

$\square 30-40 \mu \mathrm{g} / \mathrm{m}^{3} \square$ above $40 \mu \mathrm{g} / \mathrm{m}^{3}$

Fig. 4. Concentration field map of (a) Secondary OC, (b) EC, (c) gravimetric $\mathrm{PM}_{10}$, (d) gravimetric $\mathrm{PM}_{2.5}$

sulphate. Wagstroma and Pandis (2011) explained these observations by the slow processes involved in the atmospheric oxidation of $\mathrm{SO}_{2}$ and VOCs into sulphate and secondary organic aerosol. Similar local or mesoscale origins are observed for the nitrate (Fig. 3b), unlike sulphate and OC/SOC that are mainly attributed to long-range transport. This suggests that nitrate is more rapidly formed in the atmosphere than sulphate and $\mathrm{OC}$, consistent with known $\mathrm{NO}_{\mathrm{x}}$ chemistry. The high concentrations attributed to the North Sea for EC and nitrate may be an artefact due to local/mesoscale influences since such a strong influence of maritime transport emissions from this area is not seen in the EMEP emissions inventories. Indeed, a significant proportion of arctic air masses are stagnant air masses (about 47\%). Most of these air masses have crossed the North Sea before re-circulating over the British Isles and reaching Harwell. Also, because of possible local and mesoscale influences, the EC and nitrate concentration values attributed by the map may possibly be overestimated as shown by maps computed without data associated with trajectories that have crossed the London conurbation or associated with winds blowing from the local highway (see Figure 8 in Supplementary Information).
The map of gravimetric $\mathrm{PM}_{2.5}$ shows similarities to the map of nitrate and to a lesser extent to the map of sulphate. The map of gravimetric $\mathrm{PM}_{10}$ shows similarities to the maps of OC and SOC even though a local influence is also expected for $\mathrm{PM}_{10}$.

Trajectory clustering of 2006-2010 data resulted in seven trajectories that were in good agreement with the climatology of principal air masses established earlier for the British Isles (McIntosh and Thom, 1969). Using 7 backward trajectory clusters leads to results that may be discussed within the framework of established air mass characteristics over Britain (Fig. 5). Increasing the number of clusters leads to further clusters over the Atlantic Ocean that are of little interest. The number of trajectories used for classification (1788, one per day from 2006 to 2010) leads to a good significance level for the results.

The seven clusters are described with frequencies of occurrence in brackets as below:

C1: stable southerly maritime air masses including tropical maritime air masses and stable returning polar maritime air masses $(16.9 \%)$ 


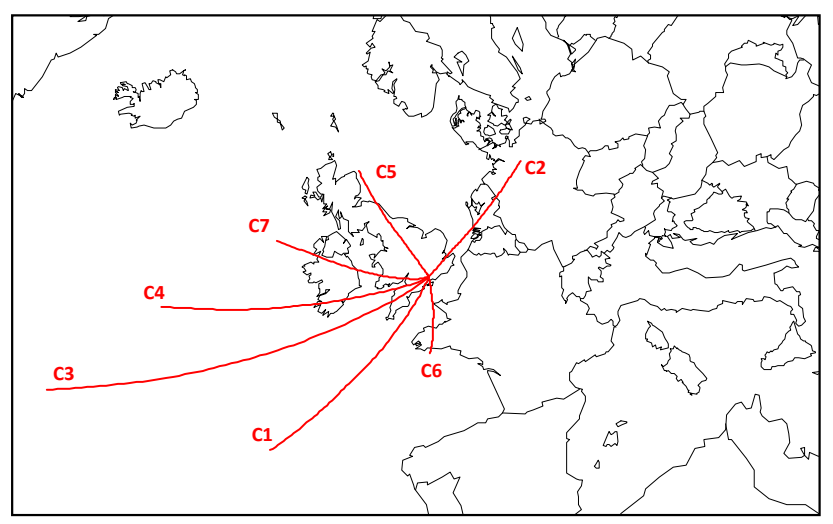

Fig. 5. Final centres of 7 clusters (K-mean partitioning method) of backward trajectories finishing at Harwell during the 2006-2010 period.

C2: polar continental air masses $(13.1 \%)$

C3: fast-moving polar maritime air masses $(9.2 \%)$

C4: polar maritime air masses slower than $\mathrm{C} 3$ and stable returning polar maritime air masses $(12.6 \%)$

C5: arctic maritime and arctic continental air masses $(14.4 \%)$

C6: includes both slow-moving tropical continental and tropical maritime air masses $(18.5 \%)$

C7: arctic and polar maritime air masses (15.2\%)

Particle concentrations measured at Harwell for each cluster are represented using box plots (Fig. 6). The upper side of the box is the 75th percentile and the lower side is the 25th percentile; the line inside the box is the median and the black circle inside the box is the arithmetic mean. The distance between the 25th and the 75th percentiles is called the Inter Quartile Range (IQR) such that $50 \%$ of the data are included within the box. The length of the upper whisker is the shorter of these two distances: the distance between the 75th percentile and the maximal value or 1.5 times the IQR and similarly, the length of the lower whisker is the shorter of these two distances: the distance between the minimal value and the 25 th percentile or 1.5 times the IQR. When the whisker is 1.5 times the IQR, very high or very low values that may be called "outlier values" are drawn outside the box plots as black circles.

In agreement with results from the CFMM and former observations by Abdalmogith and Harrison (2005), the highest concentrations of all pollutants are observed for $\mathrm{C} 2$ continental air masses (except for chloride) and the second highest for C6 slow-moving tropical air masses (again except for chloride) many of which have continental origins (the tropical continental ones). Low concentrations are associated with maritime air masses $(\mathrm{C} 1, \mathrm{C} 3, \mathrm{C} 4)$ and the lowest with the fast-moving C3 air masses. The latter air masses are associated with the strongest winds and are responsible for the highest concentrations of chloride at Harwell.

In the case of sulphate and nitrate, the continental cluster $\mathrm{C} 2$ shows the highest average concentrations exceeding those in the maritime trajectories by a factor of more than 2 . The second highest concentrations were associated with cluster C6, which includes tropical continental air masses which again had traversed the land of mainland Europe, presumably accumulating precursors which were converted to secondary particles en route. About one half of the airmasses in the C6 cluster have re-circulated over the British Isles before reaching Harwell (and about $35 \%$ of C6 trajectories were stagnant). However, the influence of stagnation on concentration values is only seen for particulate nitrate (median concentration of $2.5 \mu \mathrm{g} \mathrm{m}^{-3}$ in the case of stagnation; $1.8 \mu \mathrm{g} \mathrm{m}^{-3}$ for the other air masses - significance: $p=0.02$, Mann Whitney $\mathrm{U}$ test). The concentrations of the other particulate compounds are high and similar whether air masses have stagnated or not.

The third highest concentrations were associated with cluster C5 (Artic maritime and continental air masses). Most of these trajectories have crossed northern and central England before arriving at Harwell and almost half of them $(47 \%)$ were stagnant air masses. The large proportion of re-circulating air masses in cluster C5 may explain the quite high concentrations associated with this cluster. Indeed, all particulate concentrations (except for chloride) are significantly higher in the case of re-circulation over the U.K. than for non-stagnant air masses (median concentration for non-stagnant/stagnant airmasses - significance Mann Whitney $\mathrm{U}$ test: $\mathrm{NO}_{3}^{-}: 1.2 / 2.2 \mu \mathrm{g} \mathrm{m}^{-3}-p \dot{<} 0.001 ; \mathrm{SO}_{4}^{2-}$ : 1.3/1.9 $\mu \mathrm{g} \mathrm{m}^{-3}-p<0.001$; OC: $2.2 / 2.6 \mu \mathrm{g} \mathrm{m}^{-3}-p=0.030$; EC: $0.37 / 0.59 \mu \mathrm{g} \mathrm{m}^{-3}-p=0.047 ; \mathrm{PM}_{10}: 12.5 / 15 \mu \mathrm{g} \mathrm{m}^{-3}$ $\left.p=0.038 ; \mathrm{PM}_{2.5}: 12 / 20 \mu \mathrm{g} \mathrm{m}^{-3}-p<0.001\right)$.

A similar ranking of trajectories is seen for organic carbon and SOC, but in neither case is the ratio between continental and maritime trajectories as great as for sulphate and nitrate. The high within-cluster variability for EC probably reflects the importance of local, as opposed to long-range transport effects.

\subsection{Seasonal variations of regional source areas}

The CFMM applied to chloride, nitrate and EC for warm and cold seasons separately confirms the observed seasonal variations of these three compounds with higher concentrations during the cold season (Figs. S3, S4, S5). The CFMM applied to sulphate (Fig. S6) demonstrates the apparent absence of seasonal variation: during the cold season, higher concentrations of sulphate $\left(>4 \mu \mathrm{g} \mathrm{m}^{-3}\right)$ at Harwell are associated with European areas with high $\mathrm{SO}_{2}$ emissions that are more active during this season; while, during the warm season, higher concentrations of sulphate $\left(>2 \mu \mathrm{g} \mathrm{m}^{-3}\right)$ are quite uniformly attributed to European areas with an emphasis upon southerly 

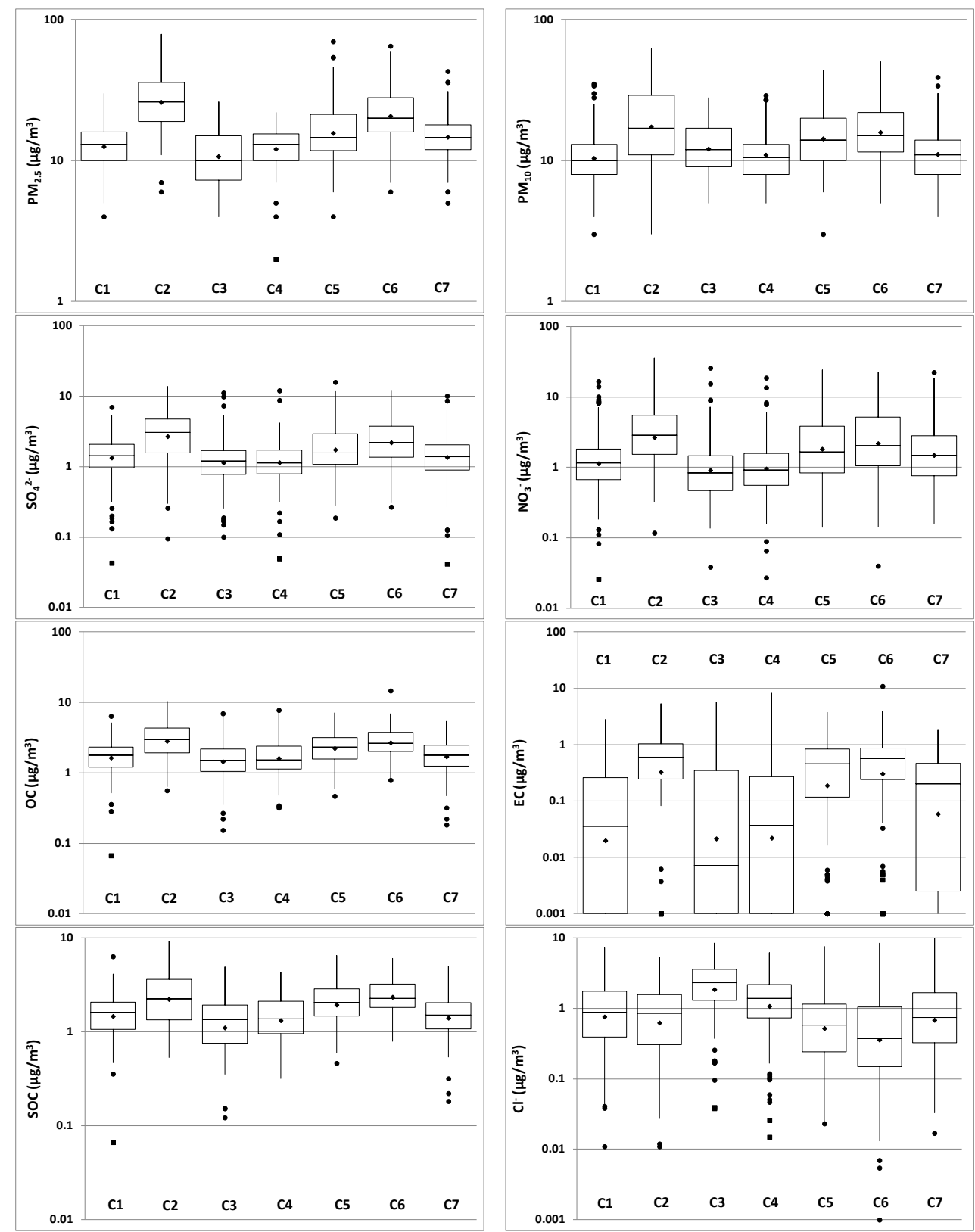

Fig. 6. Box plots for $\mathrm{PM}_{2.5}, \mathrm{PM}_{10}, \mathrm{SO}_{4}^{2-}, \mathrm{NO}_{3}^{-}$, OC, $\mathrm{EC}, \mathrm{SOC}$ and $\mathrm{Cl}^{-}$measured at Harwell for each cluster.

air masses. Any increase of sulphate during the warm season might be due to the enhancement of photochemical reactions (high solar radiation and temperatures) which facilitates the conversion of $\mathrm{SO}_{2}$ gases into $\mathrm{SO}_{4}^{2-}$ (Kouyoumdjian et al., 2006). This is in agreement with the hypothesis of Lonati et al. (2008) to explain the absence of apparent seasonal variation of sulphate.

Results for OC and SOC show similarities with sulphate (even though less obvious) with high concentrations attributed to mainland Europe during the cold season and more uniform concentrations and an emphasis upon southerly air masses during the warm season. Higher OC and SOC concentrations attributed to the Atlantic Ocean during the warm season (also observed for sulphate) suggest the more important photochemical activity during this season associated with southerly air masses assuming no emission from the ocean (Fig. S7, results not shown for SOC because they are very similar to OC). However, contrary to sulphate, the contribution of biogenic emissions of VOC during the warmer months leads to significant seasonal variations of OC concentrations at Harwell. 
An examination of seasonal variations of air masses arriving at Harwell has also been conducted using clusters of backward trajectories. Only the $\mathrm{C} 3$ air masses (fast-moving polar maritime air masses) show clear seasonal variations: these air masses are about 4 times more frequent during the months of the cold season than during the warm season. This at least partly explains the seasonal variation of chloride. The absence of seasonal variations of the other air masses indicates that the seasonal variations of the concentrations of all particulate pollutants (except chloride) could not be attributed to the seasonal variation of atmospheric transport of air masses to England.

\subsection{Composition of the aerosol and wind direction/back trajectory cluster membership}

Gravimetric $\mathrm{PM}_{10}$ data and reflectance organic carbon data have been used in the calculations. The pragmatic mass model of Harrison et al. (2003) has been used to estimate the distribution of mass amongst chemical species. This involves calculation of the mass of $\mathrm{NH}_{4} \mathrm{NO}_{3},\left(\mathrm{NH}_{4}\right)_{2} \mathrm{SO}_{4}$ and secondary organic matter and assignment of the remainder as primary. The failure to account for sea salt sulphate will have led to a small over-estimation of the ammonium sulphate mass, most notable in the south-westerly air masses and maritime clusters. The results appear in Figure 7 for the relationship with wind direction and Figure 8 for the relationship with trajectory cluster.

Unlike absolute concentrations, the average contributions of $\mathrm{NH}_{4} \mathrm{NO}_{3},\left(\mathrm{NH}_{4}\right)_{2} \mathrm{SO}_{4}, \mathrm{SOM}$ to the $\mathrm{PM}_{10}$ mass (in \%) per wind sector are quite similar (about 15-20\%, 9-12\%, 21$28 \%$ of the $\mathrm{PM}_{10}$ mass respectively). On the contrary, the average contributions of $\mathrm{NH}_{4} \mathrm{NO}_{3},\left(\mathrm{NH}_{4}\right)_{2} \mathrm{SO}_{4}, \mathrm{SOM}$ to the $\mathrm{PM}_{10}$ mass (in \%) strongly depend on back trajectory clusters (Fig. 8). Larger contributions of secondary aerosols to the $\mathrm{PM}_{10}$ mass are observed for clusters of continental air masses (secondary aerosols are up to $60 \%$ of the $\mathrm{PM}_{10}$ mass) than for clusters of maritime air masses (40-45\% of the $\mathrm{PM}_{10}$ mass). This result again highlights the significance of longrange transport for sulphate, nitrate and $\mathrm{OC}$ concentrations measured at Harwell. These figures also show, in agreement with observations in other European locations (e.g. Putaud et al., 2010; Carbone et al., 2010, Minguillon et al., 2012) the dominant contributions of ammonium sulphate, ammonium nitrate and organic matter to the PM mass.

\subsection{Elemental and organic carbon from Birmingham (EROS Site) and Harwell}

The EROS site is an urban background site within the University of Birmingham campus located within the southern suburbs of Birmingham, UK. Samples of airborne particulate matter were collected simultaneously at the EROS and Harwell sites in coarse and fine fractions using a Partisol 2025D sampler between July and November 2010. In all,

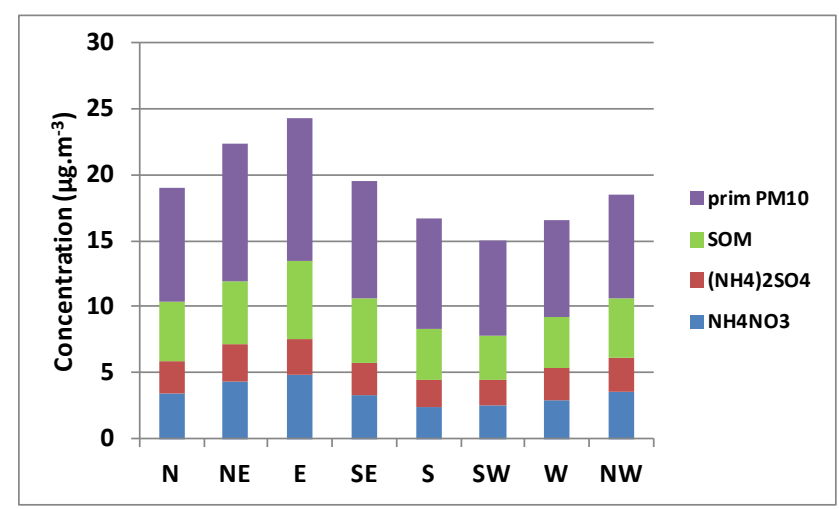

(a)

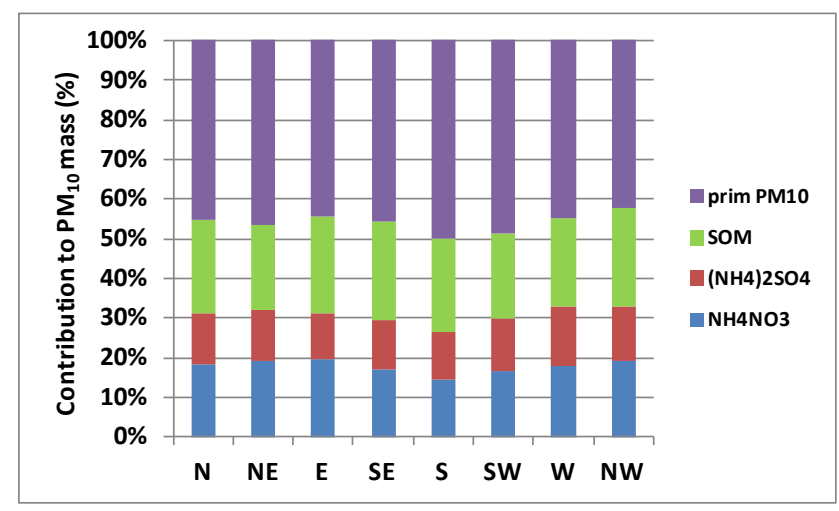

(b)

Fig. 7. Composition of PM using the pragmatic mass closure model as a function of wind sector direction (a) absolute values in $\mu \mathrm{g} \mathrm{m}^{-3}$ and (b) $\%$ of $\mathrm{PM}_{10}$ mass. SOM is secondary organic matter.

100 simultaneous 24-h samples were collected and the concentrations are summarised in Table 3. For the purposes of this table, concentrations of primary and secondary organic carbon have been derived from the OC and EC concentrations assuming a primary $\mathrm{OC} / \mathrm{EC}$ ratio of 0.35 as indicated by Pio et al. (2011) for circumstances in which road traffic is the main contributor to primary organic carbon. Consequently, any contribution from industrial emissions or wood smoke would be misclassified as secondary. However, as Pio et al. (2011) demonstrate, the use of the minimum measured ratio in the EC tracer method can be highly misleading. The data in Table 3 show a substantial excess of elemental carbon at EROS relative to Harwell consistent with the urban to rural difference between the sites. On the other hand, the spatial gradient for organic carbon is much weaker and when presented as secondary organic carbon, the inter-site differences are quite small and may be explained by a local non-traffic OC source within Birmingham (Table 3). A plot of calculated secondary $\mathrm{OC}$ at the two sites (Fig. 9) shows data scattered around a $1: 1$ relationship $\left(r^{2}=0.32\right)$ indicating that despite the considerable spatial separation between the two sites, the 


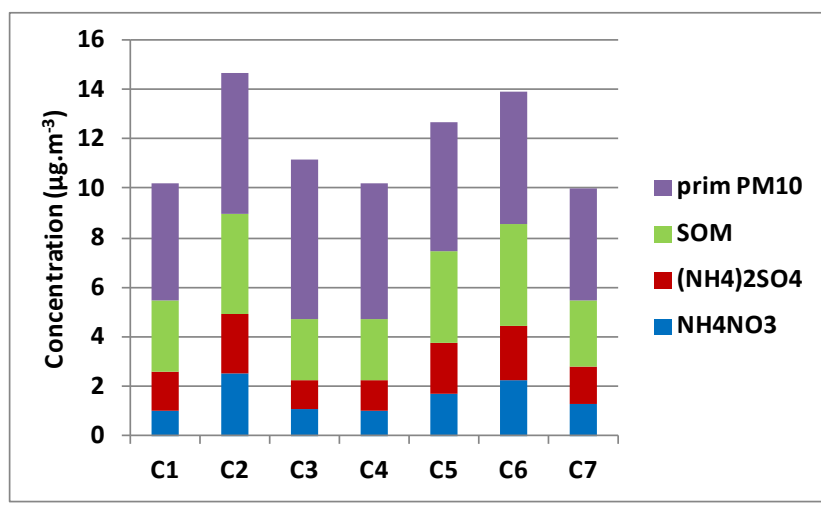

a

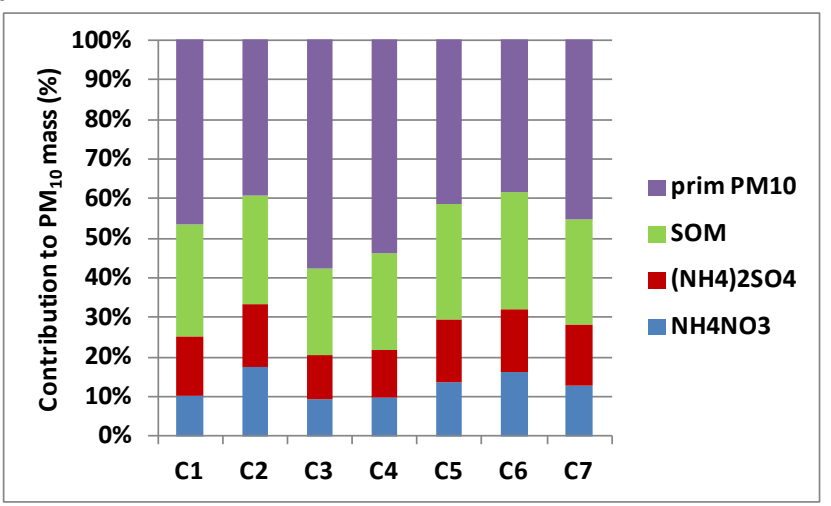

b

Fig. 8. Composition of PM using the pragmatic mass closure model as a function of back trajectory clusters (a) absolute values in $\mu \mathrm{g} \mathrm{m}^{-3}$ and (b) $\%$ of $\mathrm{PM}_{10}$ mass. SOM is secondary organic matter.

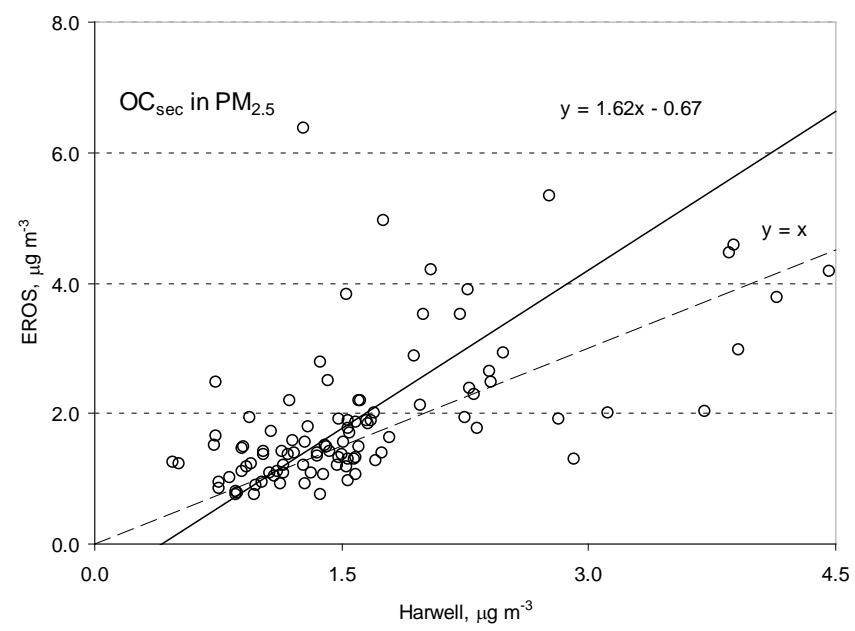

Fig. 9. Relationships between EROS and Harwell concentrations of secondary OC calculated by the OC/EC minimum ratio of 0.35 . Regression line by Reduced Major Axis method.

concentrations of secondary organic carbon are related. This further confirms the rather spatially uniform concentrations of secondary organic carbon. An examination of the rela- tionship between concentrations at Birmingham (EROS) and Harwell for sulphate and nitrate produce the following regressions:

$$
\begin{aligned}
& \text { - for sulphate, EROS }=1.09 \text { Harwell }\left(\mu \mathrm{g} \mathrm{m}^{-3}\right) r^{2}=0.67 \\
& \text { - for nitrate, } \operatorname{EROS}=1.05 \text { Harwell }+0.11 \quad\left(\mu \mathrm{g} \mathrm{m}^{-3}\right) \\
& r^{2}=0.70
\end{aligned}
$$

The inter-site relationships are clearly closer for nitrate and sulphate than for secondary organic carbon, but it should be borne in mind that the secondary organic carbon is estimated by difference and that the split between organic and elemental carbon is operationally defined and the analytical procedure may be subject to matrix effects influencing the combustion temperature of the carbon. As a consequence, there are larger uncertainties surrounding the concentration data for secondary organic carbon which would partially explain the rather weaker relationship. The fact that there was rather little enhancement of organic carbon in the airmasses travelling over London relative to those which did not (data not shown), is consistent with a rather slow formation and long persistence of secondary organic aerosol. It should be borne in mind that as SOC derives from a wide range of precursors, each reacting at a different rate, it will have both distant and more local sources and therefore be less spatially homogeneous in concentration than sulphate.

\section{Conclusions}

It is well known that pollution episodes affecting the southern United Kingdom are often associated with advection of airmasses from the European mainland. Thus, in the case of $\mathrm{PM}_{2.5}$, for example, polar plots show the highest concentrations associated with winds in an easterly sector (Harrison et al., 2012). Our earlier work (Abdalmogith and Harrison, 2005) has shown a clear association between concentrations of nitrate and sulphate and airmasses originating from continental Europe. The current study has strengthened and extended those conclusions. In this work, primary components such as chloride and EC are examined simultaneously with secondary components (sulphate, nitrate, SOC) in order to better understand the behaviour of secondary aerosol constituents. With respect to sulphate and nitrate, the work has demonstrated potential source regions which correlate strongly with EMEP maps of precursor emissions. The relative emphasis on areas in mainland Europe as opposed to the United Kingdom seen for sulphate, presumably reflects the relatively slow formation of these pollutants during atmospheric transport. In the case of nitrate, results showed both contributions from long-range transport (mainland Europe) and local/mesoscale sources as an indication of faster formation in the atmosphere of particulate nitrate than particulate sulphate. This has considerable policy relevance in highlighting the fact that cutting UK precursor emissions without 
affecting emissions in mainland Europe would be of rather limited benefit with respect to sulphate and nitrate concentrations.

The interesting extension to this work relates to carbonaceous aerosol and especially secondary organic aerosol. This shows some features similar to sulphate, with others in marked contrast. Like sulphate and nitrate, secondary organic carbon shows considerable uniformity across sites at some distance from one another. It is therefore a regional rather than a local pollutant. The concentration field map for secondary organic carbon emphasises the importance of source areas in mainland Europe showing a more southerly emphasis than for nitrate and similarities with sulphate. However, contrary to sulphate, concentrations of OC and SOC at Harwell are significantly higher during the warmer months. Since secondary organic carbon derives from both anthropogenic and biogenic precursors (Utembe et al., 2009) the southerly emphasis and seasonal variations may reflect a significant contribution from biogenic precursors whose release is favoured by higher temperature and sunshine levels. The somewhat weak difference between OC concentrations measured during warmer and colder months (contrary to other particulate compounds such as EC, chloride and nitrate that showed strong seasonality) may be due to the semi-volatile nature of SOA and the fact that it will tend to partition into the vapour phase as air temperatures increase.

The results for elemental carbon, which is a solely primary pollutant, bear far more similarity to those of the secondary pollutants than would have been anticipated. Both the dependence upon back trajectory and the concentration field maps suggest a major contribution of mainland European sources to elemental carbon concentrations at Harwell. The fact that the trajectory cluster associated with southerly air masses, many of which would have passed over France and/or Spain, show concentrations comparable with those from the east, which would have been influenced by central and northern Europe as well as in some cases having passed over London, is a clear indication of the importance of long-range transport as a source of elemental carbon at rural sites in southern England. The fact that the more westerly trajectories, which have still traversed significant distances across the UK and in some cases Ireland, show typically an order of magnitude concentration lower provides strong supporting evidence.

\section{Supplementary material related to this article is available online at: http://www.atmos-chem-phys.net/13/ 1879/2013/acp-13-1879-2013-supplement.pdf.}

Acknowledgements. Atmospheric measurements derive from the UK air quality data archive and the work of Bunthoon Laongsri. Air temperature and air masses backward trajectories were supplied by the British Atmospheric Data Centre (BADC). European emissions were supplied by the Centre on Emissions Inventories and Projection (CEIP). The authors are also grateful to IFSTTAR for financial support through a Master grant to Céline Degrendele.

Edited by: X. Querol

\section{References}

Abdalmogith, S. and Harrison, R. M.: The use of trajectory cluster analysis to examine the long-range transport of secondary inorganic aerosol in the UK, Atmos. Environ., 39, 6686-6695, 2005.

Artíñano, B. S. P., Alonso, D. G., Querol, X., and Alastuey, A.: Influence of traffic on the $\mathrm{PM}_{10}$ and $\mathrm{PM}_{2.5}$ urban aerosol fractions in Madrid (Spain), Sci. Tot. Environ., 334-335, 111-123, 2004.

Ashbaugh, L. L.: A statistical trajectory technique for determining air pollution source regions, J. Air Pollut. Control Assoc., 33, 1096-1098, 1983.

Cape, J. M., Coyle, M., and Dumitrean, P.: The atmospheric lifetime of black carbon, Atmos. Environ., 59, 256-263, 2012.

Carbone, C., Decesari, S., Mircea, M., Giulianelli, L., Finessi, E., Rinaldi, M., Fuzzi, S., Marinoni, A., Duchi, R., Perrino, C., Sargolini, T., Vardè, M., Sprovieri, F., Gobbi, G. P., Angelini, F., and Facchini, M. C.: Size-resolved aerosol chemical composition over the Italian Peninsula during typical summer and winter conditions, Atmos. Environ., 44, 5269-5278, 2010

Cavalli, F., Viana, M., Yttri, K. E., Genberg, J., and Putaud, J.-P.: Toward a standardised thermal-optical protocol for measuring atmospheric organic and elemental carbon: the EUSAAR protocol, Atmos. Meas. Tech., 3, 79-89, doi:10.5194/amt-3-79-2010, 2010.

Charron, A., Birmili, W., and Harrison, R. M.: Fingerprinting particle origins according to their size distribution at a UK rural site, J. Geophys. Res., 113, D07202, doi:10.1029/2007JD008562, 2008.

Charron, A., Birmili, W., and Harrison, R. M.: Factors influencing new particle formation at the rural site, Harwell, United Kingdom, J. Geophys. Res. 112, D14210, doi:10.1029/2007JD008425, 2007.

Charron, A., Plaisance, H., Sauvage, S., Coddeville, P., Galloo, J. C., and Guillermo, R.: Intercomparison between three receptororiented models applied to acidic species in precipitation, Sci. of the Tot. Environ., 223, 53-630, 1998.

Glavas, S. D., Nikolakis, P., Ambatzoglou, D., and Mihalopoulos, N.: Factors affecting the seasonal variation of mass and ionic composition of $\mathrm{PM}_{2.5}$ at a central Mediterranean coastal site, Atmos. Environ., 42, 5365-5373, 2008

Harrison, R. M., Jones, A. M., Lawrence, R. G.: A pragmatic mass closure model for airborne particulate matter at urban background and roadside sites, Atmos. Environ., 37, 4927-4933, 2003

Harrison, R. M., Laxen, D., Moorcroft, S., and Laxen K.: Processes affecting concentrations of fine particulate matter $\left(\mathrm{PM}_{2.5}\right)$ in the UK atmosphere, Atmos. Environ., 46, 115-124, 2012.

Heal, M. R., Naysmith, P., Cook, G. T., Xu, S., Raventos Duran, T., and Harrison, R. M.: Application of ${ }^{14} \mathrm{C}$ analyses to source apportionment of carbonaceous $\mathrm{PM}_{2.5}$ in the UK, Atmos. Environ. 45, 2341-2348, 2011.

Im, U., Markakis, K., Koçak, M., Gerasopoulos, E., Daskalakis, N., Mihalopoulos, N., Poupkou A., Kindap, T., Unal, A., and Kanakidou, M.: Summertime aerosol chemical composition in 
the Eastern Mediterranean and its sensitivity to temperature, Atmos. Environ., 50 164-173, 2012.

Jones, A. M. and Harrison, R. M.: Temporal trends in sulphate concentrations at European sites and relationships to sulphur dioxide, Atmos. Environ., 45, 873-882, 2011.

Kouyoumdjian, H. and Saliba, N. A.: Mass concentration and ion composition of coarse and fine particles in an urban area in Beirut: effect of calcium carbonate on the absorption of nitric and sulfuric acids and the depletion of chloride, Atmos. Chem. Phys., 6, 1865-1877, doi:10.5194/acp-6-1865-2006, 2006.

Lonati, G., Giugliano, M. and Ozgen, S.: Primary and secondary components of $\mathrm{PM}_{2.5}$ in Milan (Italy), Environ. Intl., 34, 665670,2008

Lupu, A. and Maenhaut, W.: Application and comparison of two statistical trajectory techniques for identification of source regions of atmospheric aerosol species, Atmos. Environ., 36, 5607-5618, 2002.

McIntosh, D. H. and Thom, A. S.: Essentials of meteorology, edited by: Mott, N. and Noakes, G. R., Wykeham Publications, London, 1969.

Minguillón, M. C., Querol, X., Baltensperger, U., and Prévôt, A. S. H.: Fine and coarse PM composition and sources in rural and urban sites in Switzerland: Local or regional pollution?, Sci. Tot. Environ., 427-428, 191-202, 2012.

Official Journal: Directive 2008/50/EC of the European Parliament and the Council of 21 May 2008 on ambient air quality and cleaner air for Europe, Official Journal of the European Union, 11.6.2008, L152, 1-44, 2008. Available at: http://eur-lex.europa.eu/LexUriServ/LexUriServ.do?uri=OJ: L:2008:152:0001:0044:EN:PDF

Pant, P. and Harrison, R. M.: Critical Review of receptor modelling for particulate matter: A case study of India, Atmos. Environ., 49, 1-12, 2012.

Park, S., Ondov, J. M., Harrison, D., and Nair, N. P.: Seasonal and shorter-term variations in particulate atmospheric nitrate in Baltimore, Atmos. Environ., 39, 2011-2020, 2005.

Parkhurst, D. F.: Arithmetic versus geometric means for environmental concentration data, Environ. Sci. Technol., 32, 92-98, 1998.

Pio, C., Cerqueira, M., Harrison, R. M., Nunes, T., Mirante, F., Alves, C., Oliveira, C., Sanchez de la Campa, A., Artinano, B., and Matos, M.: OC/EC ratio observations in europe: Re-thinking the approach for apportionment between primary and secondary organic carbon, Atmos. Environ., 45, 6121-6132, 2011.

Putaud, J.-P., Van Dingenen, R., Alastuey, A., Bauer, H., Birmili, W., Cyrys, J., Flentje, H., Fuzzi, S., Gehrig, R., Hansson, H. C., Harrison, R. M., Herrmann, H., Hitzenberger, R., Hüglin, C., Jones, A. M., Kasper-Giebl, A., Kiss, G., Kousam, A., Kuhlbusch, T. A. J., Löschau, G., Maenhaut, W., Molnar, A., Moreno, T., Pekkanen, J., Perrino, C., Pitz, M., Puxbaum, H., Querol X., Rodriguez, S., Salma, I., Schwarz, J., Smolik J., Schneider, J., Spindler, G., ten Brink, H., Tursic, J., Viana, M., Wiedensohler, A., and Raes, F.: A European aerosol phenomenology 3: Physical and chemical characteristics of particulate matter from 60 rural, urban, and kerbside sites across Europe, Atmos. Environ., 44, 1308-1320, 2010.
Revuelta, M. A., Harrison, R. M., Nunez, L., Gomez-Moreno, F. J., Pujadas, M., and Artinano, B.: Comparison of temporal features of sulphate and nitrate at urban and rural sites in Spain and the UK, Atmos. Environ., 60, 383-391, 2012.

Seibert, P., Kromp-Kolb, H., Baltensperger, U., Jost, D. T., Schwikowski, M., Kasper, A., and Puxbaum, H.: Trajectory analysis of aerosol measurements at high alpine sites, Proc. of EUROTRAC Symposium' 94, edited by: Borrell, P. M., Borrell, P., Cvitas, T., and Seiler, W., Academic Publishing BV, The Hague, Garmish-Partenkirchen, Germany, 689-693, 1994.

Simpson, D., Guenther, A., Hewitt, C. N., and Steinbrecher, R.: Biogenic emissions in Europe, J. Geophys. Res., 100, 22875-22890, 1995.

Stelson, A. W. and Seinfeld, J. H.: Relative humidity and temperature dependence of the ammonium nitrate dissociation constant, Atmos. Environ., 16, 983-992, 1982.

Stohl, A.: Trajectory statistics - A new method to establish sourcereceptor relationships of air pollutants and its application to the transport of particulate sulfate in Europe, Atmos. Environ., 30, 579-587, 1996.

Utembe, S. R., Watson, L. A., Shallcross, D. E., and Jenkin, M. E.: A common representative intermediates (CRI) mechanism for VOC degradation. Part 3: Development of a secondary organic aerosol module, Atmos. Environ., 43, 1982-1990, 2009.

Vercauteren, J., Matheeussen, C., Wauters, E., Roekens, E., van Grieken, R., Krata, A., Makarovska, Y., Maenhaut, W., Chi, X., and Geypens, B.: Chemkar $\mathrm{PM}_{10}$ : An extensive look at the local differences in chemical composition of $\mathrm{PM}_{10}$ in Flanders, Belgium, Atmos. Environ., 45, 108-116, 2001.

Wagstroma, K. M. and Pandis, S. N.: Contribution of long range transport to local fine particulate matter concerns, Atmos. Environ., 45, 2730-2735, 2011.

Wilks, D. S: Statistical methods in atmospheric sciences - An introduction, Intl. Geophysics Series, 59, edited by: Dmowska, R. and Holton, J. R., Academic Press, 1995.

Yin, J., Harrison, R. M., Chen, Q., Rutter, A., and Schauer, J. J.: Source apportionment of fine particles at urban background and rural sites in the UK atmosphere, Atmos. Environ., 44, 841-851, 2010.

Yin, J. and Harrison R. M.: Pragmatic mass closure study for $\mathrm{PM}_{1.0}$, $\mathrm{PM}_{2.5}$ and $\mathrm{PM}_{10}$ at roadside, urban background and rural sites, Atmos. Environ., 42, 980-988, 2008.

Zhao, W., Hopke, P. K., and Zhou, L.: Spatial distribution of source locations for particulate nitrate and sulfate in the uppermidwestern United States, Atmos. Environ., 41, 1831-1847, 2007.

Zhou, L., Hopke, P. K., and Liu, W.: Comparison of two trajectory based models for locating particle sources for two rural New York sites, Atmos. Environ., 38, 1955-1963, 2004. 